\title{
HUBUNGAN ANTARA ATTACHMENT IBU - ANAK DENGAN OTONOMI PADA MAHASISWA PERANTAUAN ANGKATAN TAHUN PERTAMA DI UNIVERSITAS KRISTEN SATYA WACANA
}

\author{
Fera Christin Hendriyani Day \\ Fakultas Psikologi Universitas Kristen Satya Wacana \\ dayfera20@gmail.com \\ Berta Esti Ari Prasetya \\ Fakultas Psikologi Universitas Kristen Satya Wacana \\ bertaprasetya@gmail.com
}

\begin{abstract}
Abstrak
Penelitian korelasional yang bertujuan untuk mengetahui hubungan signifikansi antara kelekatan ibuanak dengan kemandirian pada mahasiswa perantauan angkatan tahun pertama di Universitas Kristen Satya Wacana (UKSW). Penelitian dilakukan terhadap 100 siswa tahun 2017 yang berasal dari luar Pulau Jawa di UKSW, dengan menggunakan teknik kuota sampling.

Instrumen penelitian yang digunakan untuk mengukur kemandirian adalah Kuesioner Otonomi Remaja, dan instrumen yang digunakan untuk mengukur kelekatan adalah Inventory of Parent and Peer Attachment-Revisi (IPPA-R). Teknik yang digunakan adalah teknik analisis statistik untuk menguji korelasi antara dua variabel.

Hasil penelitian ini menunjukkan bahwa skor koefisien korelasi $r=0,231$, dengan sig. $=0,021(p<0,05)$. Hasil ini menunjukkan hubungan positif yang signifikan antara kelekatan ibu - anak dan kemandirian pada mahasiswa perantauan angkatan tahun pertama di UKSW. Kelekatan ibu - anak berkontribusi $5,3 \%$ terhadap munculnya perilaku kemadirian pada mahasiswa perantauan angkatan tahun pertama di UKSW, sedangkan sisanya $94,7 \%$ dapat disebabkan oleh faktor lain.
\end{abstract}

Kata kunci: Kelekatan, Kemandirian, Mahasiswa perantauan.

\begin{abstract}
This is a correlational research which aim to determine the significance correlation between Attachmet of Mother - Child and Autonomy in First-Grade in Wander Student at Satya Wacana Christian University (SWCU). Research was conducted on 100 students class of 2017 who came from outside Java island at SWCU, by using an quota sampling technique.

The research instrument which is used to measuring autonomy is Adolescent Autonomy Questionnaire, and instrument which is used to measuring attachment is Inventory of Parent and Peer AttachmentRevised (IPPA-R). Pearson Product Moment is statistical analysis technique to examine the correlation between two variable.

The result of this study showed that correlation coefficient score $r=0,231$, with sig. $=0,021(p<0,05)$. These result indicate a significant positive relationship between Attachmet of mother - child and Autonomy in first-grade wander student at SWCU. Attachment of mother - child contributed 5,3\% against the emergence of autonomous behavior in first-grade wander student at SWCU, while the rest $94,7 \%$ can be caused by others factor.
\end{abstract}

Keywords : Attachment, Autonomy, Wander Student

(C) 2018 Universitas Muria Kudus 


\section{PENDAHULUAN}

Mahasiswa merupakan peserta didik yang terdaftar dan belajar pada perguruan tinggi baik perguruan tinggi negeri maupun swasta. Mahasiswa dalam tahap perkembangannya digolongkan sebagai remaja akhir dan menuju ke dewasa awal, yaitu 18-21 tahun dan 22-24 tahun (Monks, Knoers, \& Haditono, 2002). Steinberg (Wiranti, 2013) berpendapat bahwa mempunyai kemampuan menjadi individu yang mandiri adalah salah satu tugas perkembangan dasar pada tahun-tahun pertama remaja.

Istilah otonomi umumnya berkonotasi dengan keterarahan-diri dan kemandirian (Santrock, 2007). Menurut Havirgust (Permatasari \& Kurniawan, 2002) seorang remaja yang mandiri akan mampu mengontrol emosi dan tidak tergantungnya kebutuhan emosi dari orang tua, ia juga dapat mengatur perekonomiannya dengan baik. Nashori (Warsito, 2013) mengatakan kemandirian merupakan salah satu ciri kualitas hidup manusia yang mempunyai peran penting bagi kesuksesan dalam hidup bangsa ataupun hidup secara mandiri. Nuryoto (Warsito, 2013) selain itu individu yang mempunyai kemandirian kuat akan lebih mampu bertanggung jawab, beradaptasi terhadap perubahan lingkungan, berani menghadapi masalah dan resiko, serta tidak terpengaruh ataupun bergantung pada orang lain.

Dengan memiliki otonomi, remaja dapat berangsur-angsur melepaskan diri dari ketergantungan pada orang tua atau orang dewasa lainnya dalam banyak hal. Apabila dari masa remaja sudah memiliki otonomi, maka ketika dewasa, remaja tadi akan menjadi orang dewasa yang memiliki otonomi, dan mampu menjalankan tugasnya sebagai manusia dewasa dengan baik (Permatasari \& Kurniawan, 2002).

Berdasarkan hasil pengamatan peneliti terhadap mahasiswa tingkat awal yang merantau di Universitas Kristen Satya Wacana (UKSW), menunjukkan sikap yang tergantung pada orang tua, dimana selalu bertanya kepada orang tua mengenai sesuatu hal yang ingin ia lakukan, misalnya ingin membeli makan, ingin mengikuti lomba di kampus, ingin mengambil mata kuliah, ingin membeli buku, ingin memilih teman, ingin membeli peralatan kuliah. Mereka harus menanyakan dahulu kepada orang tua, tanpa bisa mengambil keputusan sendiri. Selain hal-hal tersebut, mahasiswa yang merantau di UKSW juga melakukan perilaku merokok, meminum-minuman keras, membolos kelas, berpacaran hingga hamil diluar nikah, tidak mengerjakan tugas kuliah, bermain game dalam jumlah waktu yang lama. Hal-hal ini berakibat pada terganggunya proses perkuliahan mereka bahkan sampai ada harus drop out dari kuliah. Mereka mengaku bahwa hal-hal tersebut mereka lakukan karena ikut-ikutan teman dan merasa tidak ada pengontrolan langsung dari orang tua karena berada jauh dari orang tua.

Terdapat beberapa faktor yang memengaruhi pencapaian otonomi, sesuai dengan penjelasan Steinberg (2002) bahwa otonomi pada remaja terkait dengan hubungan, kelekatan 
(attachment) antara remaja- dengan orang tuanya, juga pola asuh yang diterapkan oleh orang tuanya.

Indrawati \& Fauziah (2012) berpendapat seseorang yang dibesarkan di lingkungan keluarga ternyata sangat berdampak pada kehidupannya sampai dewasa. Pola asuh yang ditanamkan oleh orang tuanya sejak kecil menjadi modal dasar seseorang dalam menjalani kehidupan dan melakukan interaksi dengan lingkungan sekitar dia berada.

Armsden \& Greenberg (1987) berpendapat bahwa attachment anak pada orang tua sebenarnya adalah hal yang positif, selama attachment tersebut adalah attachment yang sehat, dalam batas yang wajar, dan tidak berlebihan, attachment yang aman.

Eliasa (Purnama \& Wahyuni, 2017) mengatakan ibu adalah orang yang menduduki peringkat pertama sebagai figur lekat utama pada anak, karena ibu biasanya lebih banyak berinteraksi dengan anak dan berfungsi sebagai orang yang memenuhi kebutuhan serta dapat memberikan rasa nyaman. Menurut Liliana (Purnama \& Wahyuni, 2017) kebutuhan akan attachment pada ibu menjadi hal penting di dalam kehiduoan seseorang karena menjadi salah satu langkah awal di dalam proses perkembangan dan sosialisasi.

Penelitian mengenai otonomi dan kualitas attachment sebelumnya dilakukan oleh Hurst (2010) di luar negeri, menunjukkan hasil bahwa anak yang memiliki nilai attachment cukup tinggi dengan orang tua nya mengindikasikan tingkat otonomi yang lebih tinggi dibandingkan dengan anak yang memiliki nilai attachment lebih rendah.

Demikian pula penelitian di Indonesia yang dilakukan oleh Permatasari \& Kurniawan (2002), Dewi \& Valentina (2013), serta Prabowo \& Aswanti (2014), ketiganya menemukan hasil bahwa attachment pada orang tua memiliki hubungan yang positif dan signifikan dengan otonomi/kemandirian pada remaja.

Berdasarkan berbagai penjelasan di atas, peneliti tertarik untuk melakukan penelitian tentang hubungan antara attachment ibu - anak dengan otonomi pada mahasiswa perantauan angkatan tahun pertama di Universitas Kristen Satya Wacana.

\section{METODE PENELITIAN}

\section{Variabel Penelitian}

Menurut Martono (2016) variabel adalah pusat penelitian yang terdapat di dalam penelitian kuantitatif. Variabel dalam penelitian ini terdiri dari dua bagian yaitu, variabel independen $(X)$ dan variabel dependen $(Y)$. Variabel $X$ adalah attachment ibu - anak dan variabel $Y$ adalah otonomi.

\section{Populasi dan Sampel Penelitian}

Periantalo (2016) berpendapat bahwa populasi adalah subjek keseluruhan dari penelitian. Populasi dalam penelitian ini adalah seluruh mahasiswa/i di Universitas Kristen Satya Wacana. 
Teknik pengambilan sampel dalam penelitian ini menggunakan teknik sampling kuota adalah teknik pengambilan sample yang dilakukan dengan mengambil sejumlah kuota dari populasi yang tersedia dan menghentikan pengambilan sample setelah kuota terpenuhi (Purwanto, 2011).

\section{Teknik Pengumpulan Data}

Teknik pengumpulan data yang digunakan dalam penelitian ini adalah metode skala dengan model Likert. Skala pengukuran yang digunakan dalam penelitian ini adalah skala otonomi dan skala attachment.

\section{Teknik Analisis Data}

Keseluruhan teknik analisis data dalam penelitian ini menggunakan SPSS 16.0 for windows. Pengujian hipotesis dan korelasi antara attachment dengan otonomi menggunakan Pearson Product Moment.

\section{HASIL DAN PEMBAHASAN}

\section{Uji Validitas dan Reliabilitas}

Hasil Uji Validitas

Skala otonomi terdiri dari 15 aitem, terdapat 6 aitem yang gugur dengan koefisien 0,114 sampai 0,256 , dan 9 aitem valid dengan koefisien 0,319 sampai 0,533 . Sedangkan, skala attachment terdiri dari 25 aitem, terdapat 5 aitem yang gugur dengan koefisien 0,054 sampai 0,271 , dan 20 aitem valid dengan koefisien 0,300 sampai 0,731 .

Hasil Uji Reliabilitas

Skala otonomi memiliki nilai reliabilitas crobach's alpha sebesar 0,728 ( $r>0,05)$. Sementara, skala attachment memiliki nilai reliabilitas crobach's alpha sebesar 0,895 $(r>0,05)$.

\section{Uji Asumsi}

Uji Normalitas Sebaran

Hasil uji normalitas pada variabel attachment menunjukkan nilai K-S Z sebesar 1,128 dengan $p$ sebesar $0,157 \quad(p>0,05)$. Sedangkan uji normalitas pada variabel otonomi menunjukkan nilai K-S Z sebesar 0,827 dengan $p$ sebesar 0,502 ( $p>0,05)$. Hal ini berarti bahwa kedua variabel tersebut memiliki sebaran data yang normal.

Uji Linearitas Hubungan

Hasil uji lineritas menunjukkan nilai deviation from linearity sebesar 0,643 ( $p>0,05)$. $\mathrm{Hal}$ ini berarti bahwa ada hubungan linear antara attachment dengan otonomi.

\section{Uji Hipotesis}

Uji hipotesis dengan teknik Pearson Product Moment menunjukkan $r_{x y}$ sebesar 0,231 dengan $p$ sebesar $0,021(p<0,05)$. Hal ini berarti bahwa ada hubungan yang positif dan signifikan antara attachment ibu - anak dengan otonomi. Untuk itu, hipotesis yang diajukan oleh peneliti diterima. 


\section{Diskusi}

Hasil penelitian ini menunjukkan adanya hubungan yang positif dan signifikan antara attachment ibu - anak dengan otonomi. Dengan demikian attachment berkorelasi positif terhadap otonomi seseorang. Sekalipun hasil koefisien korelasi kedua variabel $\left(r_{x y}\right)$ hanya sebesar 0,231, hal ini menunjukkan tingkat hubungan yang rendah dimana menurut Sugiyono (2011) koefisien korelasi 0,200 - 0,399 termasuk dalam tingkat hubungan yang rendah.

Selain itu, hasil analisis data yang telah dilakukan membuktikan sekaligus menjawab hipotesis penelitian bahwa terdapat hubungan yang signifikan antara attachment ibu - anak dengan otonomi, hal ini terlihat dari signifikansi nya sebesar 0,021 . Penelitian ini sejalan dengan penelitian yang dilakukan oleh Prabowo \& Aswanti (2014), yang mendapatkan hasil bahwa attachment ibu - anak memiliki hubungan yang signifikan dengan otonomi/kemandirian.

Permatasari \& Kurniawan (2002) mengatajkan bahwa salah satu indikasi attachment terhadap orang tua adalah ketersediaan orang tua bagi anaknya. Gunarsa \& Gunarsa (Wiranti, 2013) menyatakan bahwa kedudukan ibu merupakan tokoh sentral dalam kehidupan anak. Kepedulian ibu terhadap anak dianggap sebagai suatu reaksi naluriah, sehingga hubungan positif antara remaja dan ibu dapat membentuk kemandirian secara kognitif maupun secara emosional.

Penelitian ini juga menujukkan $\mathrm{R}$ square $\left(\mathrm{r}^{2}\right)$ sebesar 0,053. Artinya, attachment ibu anak memberikan kontribusi sebesar $5,3 \%$ terhadap otonomi. Sedangkan sisanya $94,7 \%$ dipengaruhi oleh variabel lain yang tidak diteliti dalam penelitian ini. Faktor lain yang mungkin memengaruhi otonomi pada remaja adalah jenis kelamin, sistem pendidikan, sistem kehidupan di masyarakat, urutan kelahiran serta pola asuh.

\section{SIMPULAN}

\section{Kesimpulan}

Berdasarkan hasil penelitian dan analisis data, disimpulkan bahwa hipotesis penelitian dapat diterima. Dimana ada hubungan yang signifikan antara attachment ibu - anak dengan otonomi pada mahasiswa perantauan angkatan tahun pertama di Universitas Kristen Satya Wacana.

\section{Saran}

Berdasarkan hasil penelitian yang diperoleh, maka peneliti menyarankan hal-hal yang ditujukan kepada pihak tertentu, yaitu :

\section{Bagi Orang Tua}

Orang tua diharapkan dapat menjalin hubungan yang menimbulkan rasa aman pada remaja, sehingga remaja dapat mempelajari lingkungan di luar keluarga dengan lebih baik dan percaya diri. Selain itu, dapat membangun komunikasi yang terbuka dan bersifat dua 
arah, serta remaja juga perlu diberikan kesempatan dan dorongan untuk mengembangkan kemandiriannya.

\section{Bagi Mahasiswa}

Mahasiswa diharapkan untuk tetap mempertahankan attachment dengan orang tua sebagai figur attachment, dimana mahasiswa bisa membangun komunikasi dan kepercayan dengan orang tua, dengan demikian orang tua bisa memberikan kepercayaan untuk mahasiswa mengeksplor dunia nya dengan baik dan bertanggungjawab agar otonomi mahasiswa pun bisa berkembang. Terutama mahasiswa perantauan yang jauh dari orang tua dan keluarga.

\section{Bagi Peneliti Selanjutnya}

Peneliti yang ingin meneliti topik yang serupa, diharapkan mempertimbangkan faktorfaktor lain yang berpengaruh terhadap attachment dan otonomi. Selain itu, diharapkan membuat alat ukur dengan memperhatikan pilihan jawaban yang disediakan, kalimat, dan bahasa yang digunakan.

\section{DAFTAR PUSTAKA}

Armsden, G. C.,\& Greenberg, M. T. (1987). The inventory of parent and peer attachment: individual differences and their relationship to psychological well-being in adolescence. Journal of Youth and Adolescence, 427-454.

Armsden, G. C.,\& Greenberg, M. T. (2009). Inventory of parent and peer attachment (IPPA). college of health and human development, 1-12.

Dewi, A. A., \& Valentina, T. D. (2013). Hubungan kelekatan orang tua-remaja dengan kemandirian pada remaja di SMKN 1 Denpasar. Jurnal Psikologi Udayana, 181-189.

Hurst, J. R. (2010). The development of adolescent autonomy: contribustions of the motherchild attachment relationship and maternal sensitivity. The university of Texas at Dallas, 1-65.

Indrawati, E.S \& Fauziah, N. (2012). Attachment dan Penyesuaian Diri Dalam Perkawinan. Jurnal Psikologi Undip. Vol 11. No 1.

Martono, N. (2016). Metode Penelitian Kuantitatif. Jakarta : Rajawali Pers.

Monks, F. J., Knoers, A. M., \& Haditono, S. R. (2002). Psikologi Pekembangan Pengantar dalam Berbagai Bagiannya. Yogyakarta: Gadjah Mada University Press.

Murphy, D. A., Greenwell, L., Resell, J., Brecht, M.-L., \& Schuster, M. A. (2008). Early and middle adolescent's autonomy development. Clinical child psychology psychiatry, 253276.

Noom, M. J., Dekovic, M., \& Meeus, W. (2001). Conceptual analysis and measurement of adolescent autonomy. Journal of youth and adolescence, 577-595. 
Permatasari, N. I., \& Kurniawan, I. N. (2002). Hubungan antara kelekatan terhadap orang tua dengan otonomi pada remaja. Jurnal psikologi UII, 1-12.

Prabowo, R. D., \& Aswanti, M. (2014). Hubungan attachment ibu-anak dan ayah-anak dengan kemandirian pada remaja akhir. Jurnal psikologi UI, 1-16.

Purnama, R.A \& Wahyuni, S. (2017). Kelekatan (Attachment) pada lbu dan Ayah Dengan Kompetensi Sosial pada Remaja. Jurnal Psikologi. Vol 13. No 1.

Santrock, J. (2007). Remaja. Jakarta: Erlangga.

Steinberg, R. (2002). Adolescence. Boston: Mc Graw Hill.

Sugiyono. (2011). Statistika Untuk Penelitian. Bandung: Alfabeta.

Periantalo, J. (2016). Penelitian Kuantitatif Untuk Psikologi. Yogyakarta : Pustaka Pelajar.

Purwanto.(2010). Statistika Untuk Penelitian.Yogyakarta : Pustaka Pelajar.

Warsito, Lidya Irene S.S.H. (2013). Perbedaan Tingkat Kemandirian dan Penyesuaian Diri Mahasiswa Perantauan Suku Batak Ditinjau Dari Jenis Kelamin. Jurnal Character, Vol 01. No 02.

Wiranti, A. (2013). Hubungan Antara Attachment Terhadap lbu dengan Kemandirian pada Remaja Tunarungu. Jurnal Psikologi Pendidikan dan Perkembangan. Vol 2. No 01. 